\title{
Relative growth and reproductive cycle of the date mussel Lithophaga lithophaga (Linnaeus, 1758) sampled from the Bizerte Bay (Northern Tunisia)
}

\author{
Ferdaous Jaafar Kefi $\cdot$ Samir Boubaker • \\ Najoua Trigui El Menif
}

Received: 28 October 2013/Revised: 22 May 2014/Accepted: 23 May 2014/Published online: 7 June 2014 (C) Springer-Verlag Berlin Heidelberg and AWI 2014

\begin{abstract}
Relative growth and the reproductive cycle of the date mussel Lithophaga lithophaga were studied from September 2002 to October 2003 in the Bizerte Bay (Northern Tunisia). Relationships between shell length and shell width, shell height as well as volume-related variables (shell dry weight, soft tissues dry weight and total wet weight) showed negative allometries in both sexes except for shell width in males (isometry) and shell height in both sexes (positive allometry). The sex ratio was unbalanced, within the length range of $6-48 \mathrm{~mm}, 49.43 \%$ of the animals were males, $24.39 \%$ females and $26.17 \%$ sexually undifferentiated; within the length range of $49-92 \mathrm{~mm}$, the respective values were $41.19,52.7$ and $6.1 \%$. Histological investigations as well as analyses of the condition index and the gonadosomatic index (CI and GSI) revealed the presence of a single reproductive cycle per year. Spawning occurred at the end of August and early September and was associated with a decrease in seawater temperature and salinity. A resting phase occurred in winter, coinciding with the lowest water temperatures. Histological examinations of the gonads of a total of 130 specimens revealed only two cases of hermaphroditism. The present study constitutes a useful baseline for a sustainable management of local wild stocks of L. lithophaga.
\end{abstract}

Communicated by H.-D. Franke.

F. J. Kefi $(\bowtie) \cdot$ N. T. E. Menif

Laboratory of Environment Bio-monitoring, Faculty of Sciences

of Bizerte, University of Carthage, 7021 Zarzouna, Bizerte,

Tunisia

e-mail: ferdaous_j@yahoo.fr

S. Boubaker

Laboratory of Human and Experimental Pathology, Pasteur

Institute of Tunis, 13 Place Pasteur, 1002 Tunis, Tunisia
Keywords Lithophaga lithophaga · Hermaphroditism · Growth · Reproductive cycle · Bizerte Bay

\section{Introduction}

Rock-boring bivalves are an important component of rocky marine ecosystems (Guidetti and Boero 2004; Devescovi et al. 2005). The endolithic bivalve Lithophaga lithophaga (Linnaeus 1758) is part of this community, digging into limestone by means of chemical secretions (Morton and Scott 1980; Mojetta and Ghisotti 1996; Owada 2009). In their tunnels, individuals can live for 50 years or more (Katsanevakis et al. 2008). This gonochoristic bivalve is most abundant in the midlittoral and sublittoral zones (Galinou-Mitsoudi and Sinis 1994). The species is distributed along Atlantic coasts from Portugal to Senegal and further to the north of Angola (Gonzalez et al. 2000). Furthermore, it occurs throughout Mediterranean coasts (Fischer et al. 1987; Gonzalez et al. 2000).During the last decades, L. lithophaga has been intensively exploited in some European countries such as the former Yugoslavia and Spain (Poutiers 1987), and also in parts of the Moroccan Mediterranean coast (Shafee 1999). Due to the species' organoleptic quality and thus extremely high price (Devescovi 2009), it is often collected and sold even where this is inhibited by law (Devescovi and Iveša 2008). In Italy, for example, $L$. lithophaga is greatly appreciated as seafood, reaching a commercial value of up to $60 € / \mathrm{kg}$ (FAO 2004). Illegal harvesting causes significant environmental damage (Gargominy et al. 1999), affecting fish population dynamics and rocky reef ecosystem functioning with a significant local decrease in species richness and abundances (Fraschetti et al. 2001; Guidetti et al. 2002, 2003; 
Guidetti and Boero 2004). In this context, Guidetti et al. (2003) have assessed the distribution patterns of two species of sea urchins, Paracentrotus lividus (Lamarck 1816) and Arbacia lixula (Linnaeus 1758), and barren habitats (coralline barrens and bare substrates) in rocky reefs impacted by the destructive fishery for L. lithophaga (SW Apulia, Italy). Their results showed that the date mussel fishery may have the potential to affect distribution patterns of sea urchins and to greatly enhance the percent cover of barren grounds in shallow Mediterranean rocky reefs. The restoration of communities destroyed during the extraction of $L$. lithophaga is very slow and often impossible due to the fact that this species is rather long-lived with a growth rate which is one of the slowest among bivalves (Katsanevakis et al. 2008).

The date mussel was subject of several studies dealing with its biology, population dynamics, fecundity and habitat (Šimunović et al. 1990; Galinou-Mitsoudi and Sinis 1994, 1995, 1997; Jaafar Kefi et al. 2007; Devescovi 2009). Some other studies focused on the impact of harvesting and overexploitation on marine ecosystem and Mediterranean rocky coasts (Fanelli et al. 1994; Parravicini et al. 2009). Besides the important ecological role of L. lithophaga in recent ecosystems, its fossils have been used in paleoecological and paleogeographic studies for dating some geological periods and indicating submergence phases (Gilli and Audra 2004; Ballèvre and Lardeux 2005). Ecotoxicological investigations focussing on polycyclic aromatic hydrocarbons (PAH) (Dujmov and Sučević 1990) and persistent organic pollutants (POPs) (Deudero et al. 2007), suggested that the species can be used as indicator in biomonitoring programs.

In Tunisia, studies on the date mussel have been scarce and mainly limited to shell disturbances and health status (Jaafar Kefi et al. 2004, 2012a, b; Trigui El Menif et al. 2007; El bour et al. 2008). The aim of the present work is to collect data on the bio-ecology of L.lithophaga, based on samples gently taken from some areas along the northern Tunisian coast. These data were expected to provide a useful baseline for a future management of this endangered bivalve.

\section{Materials and methods}

From September 2002 to October 2003, monthly sampling of calcareous rocks at approximately three meters depth was carried out by diving in the infralittoral zone of the Bizerte Bay (northern Tunisia) (Fig. 1). In this area, the date mussel habitat shows a wakstone texture that dates from the tertiary and more precisely the Eocene era (Jaafar Kefi et al. 2004; Trigui El Menif et al. 2007). Surface seawater temperature, salinity, and oxygen were measured monthly in the study site at the time of sampling, while the $\mathrm{pH}$ value was measured only once per season. In the laboratory, the rocks were broken by a hammer and date mussel bivalves were extracted. Biometric variables were assessed for a total number of 975 specimens with a size range from 8.0 to $90 \mathrm{~mm}$.

The shell length $(L)$, width $(W)$ and height $(H)$ were measured to the nearest $0.1 \mathrm{~mm}$ using a vernier caliper. The shell was opened, and the soft parts of the organism were carefully removed and examined under a stereomicroscope. Sexing was based on gonad color and microscopic observations of gonad smears.

Shell dry weight (S d.w.), soft tissues dry weight (ST d.w.) and total wet weight (Tw.w.) were determined using a precision balance $(0.001 \mathrm{~g})$. The dry weights of shells and soft tissues were measured for each individual after drying at $60 \mathrm{C}$ to constant weight.

In order to describe relative growth, relationships were established between shell length $(x)$ and other biometric variables [W, H, S d.w., ST d.w. and Tw.w.] by fitting power functions $\left(y=b x^{\mathrm{a}}\right)$ for the linear variables and logarithmic functions $(\log y=a \log x+\log b)$ for the volume-related variables, with " $a$ " as the coefficient of allometry and "log $b$ " as the intercept. To determine whether " $a$ " was different from 1 (linear variables) and 3 (volume-related variables), respectively, $t$ tests were performed following Mayrat (1959). In this way, the type of relative growth (negative allometry for $a<1$ or $a<3$; isometry for $a=1$ or $a=3$; and positive allometry for $a>1$ or $a>3$ ) was determined.

Coefficients of allometry were compared between sexes by an analysis of covariance (ANCOVA) with shell length as covariable (Zar 1984) using the software STATISTICA 10 (significance level $P<0.05$ ).

Gonad smears of 1,340 specimens collected from September 2002 to October 2003 were examined microscopically. This allowed for calculating the sex ratio and assessing the gonadal cycle using the staging of Lucas (1965):

- Stage A: The genital gland is not discernible, and sex identification thus not possible.

- Stage B: The genital gland is discernible, but still transparent. Sex can be determined by microscopic observation.

- Stage C: The genital gland is well developed and inflated by the genital products. In an early phase of stage $\mathrm{C}(\mathrm{Ca})$, most eggs are stalked and sperm are grouped in rosettes and still largely immobile. In a subsequent phase of stage $\mathrm{C}(\mathrm{Cb})$, all eggs are stalked and invade the gonad tubes; sperm are highly mobile.

The reproductive cycle was investigated in both sexes using two biophysiological indices: the condition index 
Fig. 1 Map of Tunisia and location of the sampling site (asterics) of Lithophaga lithophaga in the Bay of Bizerte

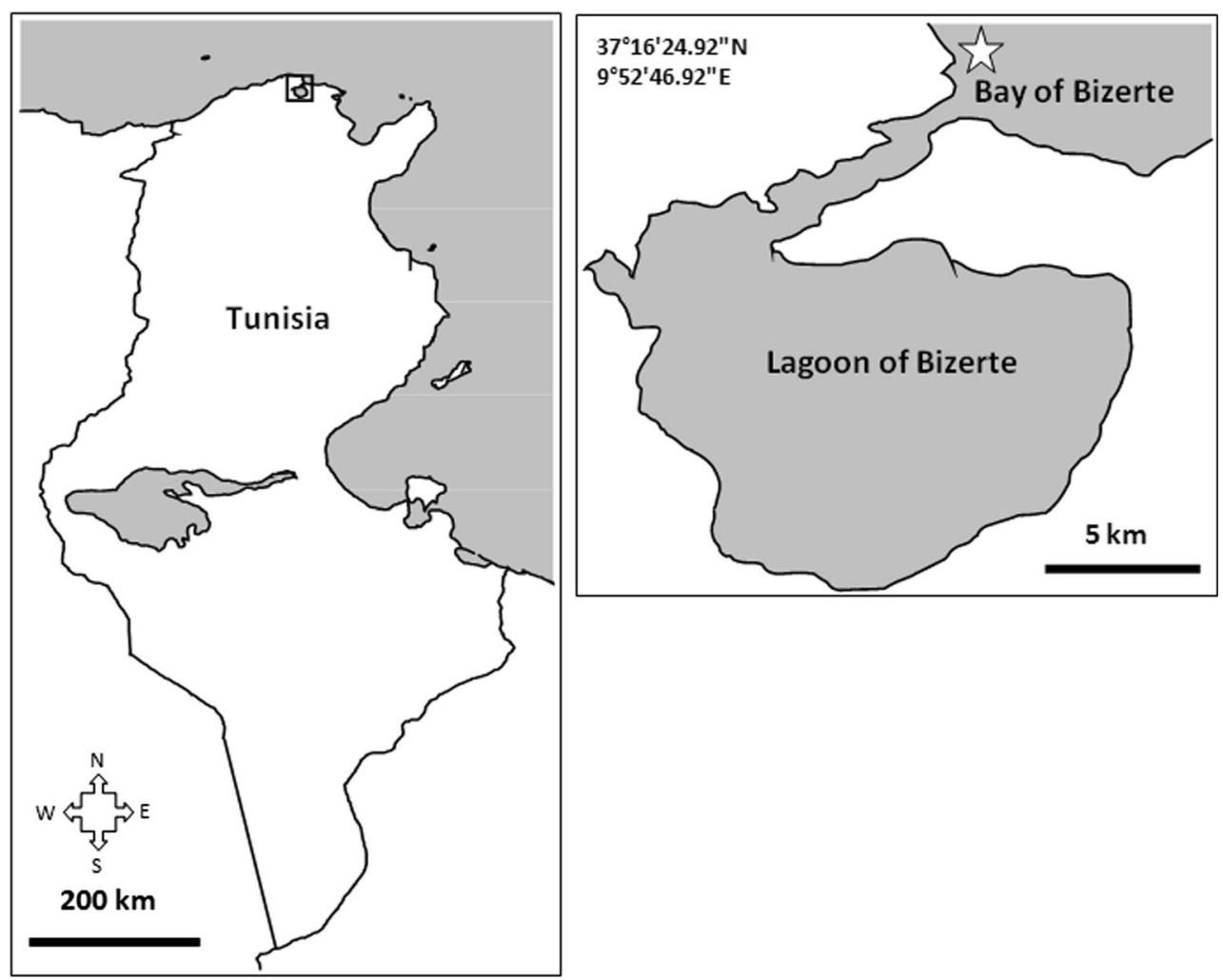

(CI) according to Walne and Mann (1975) and calculated as $\mathrm{CI}=$ (soft tissues dry weight/shell dry weight $) \times 100$; and the gonadosomatic index (GSI) calculated as GSI $=$ (dry weight of the digestive gland-gonad complex/ shell dry weight) $\times 100$.

Monthly changes in the biophysiological indices were analyzed and compared between the sexes by a one-way ANOVA. Pairwaise comparisons between the same month in males and females were made using Tukey's test (Sigma stat 3.5, statistical. significance level at $P<0.05$ ).

To allow for a clear distinction of reproductive periods, ten specimens (five males and five females) per month were studied histologically. The shell length of these specimens varied between 40 and $60 \mathrm{~mm}$. The soft parts were carefully removed from their shells, and the gonads were fixed in Bouin liquid for $48 \mathrm{~h}$ and then stored in $70 \%$ alcohol. Sections (5 mm thick) were taken from each specimens, dehydrated in an ascending alcohol series and embedded in pure paraffin (toluene was used for substitution). Gonad sections of $5 \mu \mathrm{m}$ were stained with hematoxylin-eosin (HE) and Masson's Trichrome for standard histopathological assessment. Histological sections were examined under a light microscopy (Martoja and Martoja 1967). A chi-square test was employed to test for a balanced sex ratio in the studied population of L. lithophaga using the software R 2.14.1.

\section{Results}

Environmental parameters

The seawater temperature during the study period ranged between $11.5^{\circ} \mathrm{C}$ in January and $35.0^{\circ} \mathrm{C}$ in August (Fig. 2a). The annual average was $21.8^{\circ} \mathrm{C}$.

The salinity was high for most of the year, reaching 37.9 in September, and low in rainy season with 20.5 in January. The annual average was 34.82 (Fig. 2b). The average content of dissolved oxygen was $6.64 \mathrm{mg} / \mathrm{l}$. The extreme values were recorded in August $(5.1 \mathrm{mg} / \mathrm{l})$ and January (8.25 mg/l) (Fig. 2c). The $\mathrm{pH}$, measured only once per season, was rather constant, ranging between 7.43 in autumn and 8.29 in summer (Fig. 2d).

\section{Relative growth}

All biometric variables studied were significantly correlated with shell length (Tables 1, 2).

On an annual basis, shell length (sexes confounded) grew faster than shell width, although the relationship was inverse in autumn and summer (Table 1).

When analyzing separately males and females, a negative allometry was found for females in the relationship $W$ on $L$, while this relationship was isometric in males (Table 2). 

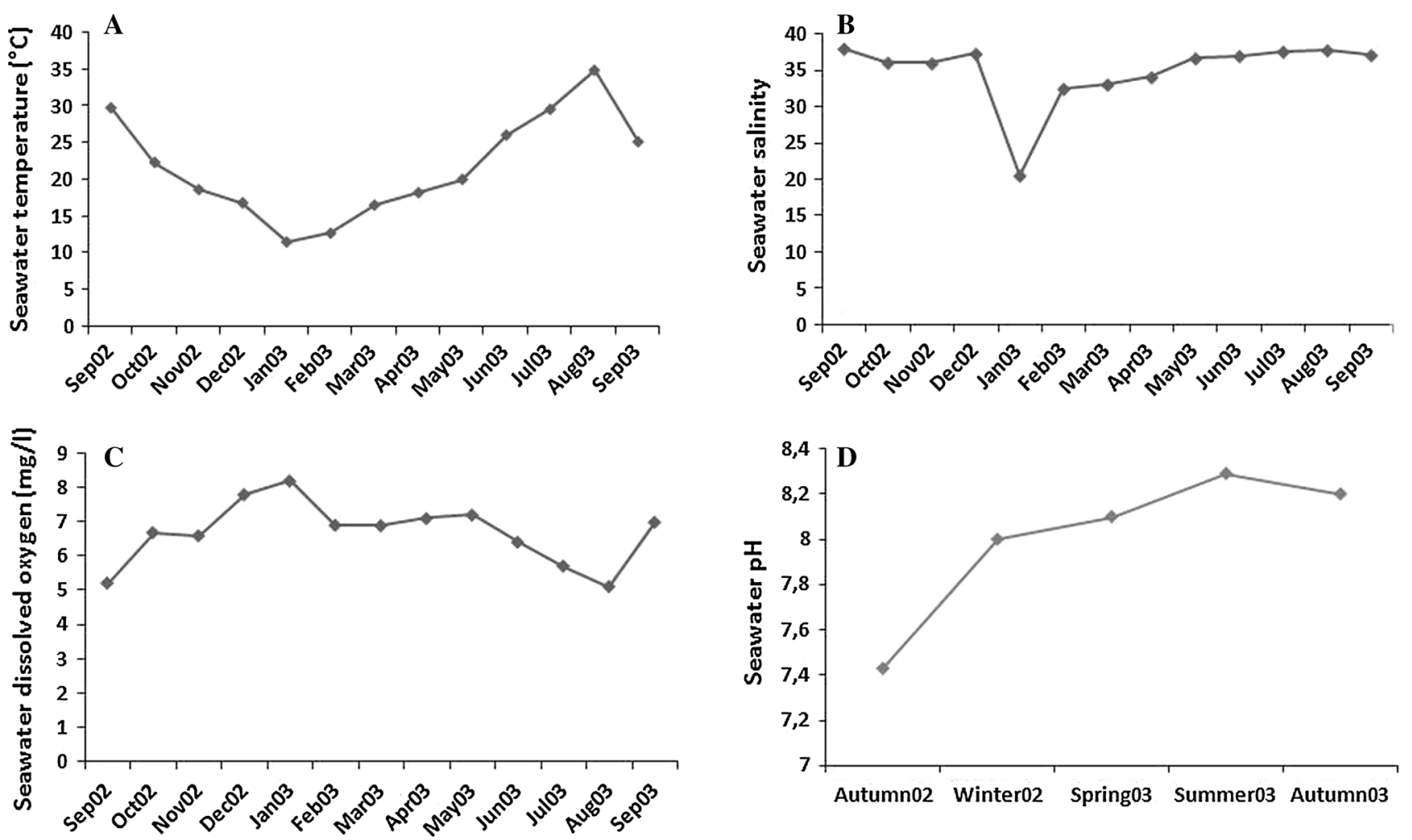

Fig. 2 Monthy variations in sea surface temperature (a), salinity (b), level of dissolved oxygen (c) and pH (d) in the Bay of Bizerte during the study period (Sept 2002-Sept 2003)

The shell height increased at a higher rate than shell length during almost all year, except for winter when no difference was found (Table 1). Both females and males displayed a positive allometry in the relationship $H$ on $L$ (Table 2).

Concerning the relationships between linear and volume-related variables, a negative relative growth was recorded for both sexes in $\mathrm{S} \mathrm{d}$. w. on $L$ (Tables 1,2 ). The growth in shell length was significantly faster than that of the soft tissues dry weight in autumn, spring and summer, while no difference was found in winter (Table 1). No difference was also found between the sexes (Table 2). For all four seasons, and in both sexes, shell length increased faster than total wet weight (Tables 1, 2).

The ANCOVA test showed significant differences between sexes for all biometric variables. The comparison of slopes showed that males grew faster than females (Table 3).

Sex ratio

The gonad of L. lithophaga forms two lateral masses occupying most of the antero-dorsal part of the animal. The color of the gonad is orange in females and pearly in males. From a total of 1,340 specimens analyzed, 531
(39.6\%) were females, $603(45.0 \%)$ were males and 206 $(15.4 \%)$ were sexually undifferentiated. The studied population thus presented a statistically unbalanced sex ratio $\left(\chi^{2}=8.89, d f=1, P=0.002\right)$. Furthermore, it presented a broad size range (shell length) from 6 to $92 \mathrm{~mm}$. The size-frequency distribution revealed that individuals were most abundant at lengths ranging between 49 and $92 \mathrm{~mm}$ (53.81 \%) (Fig. 3). Males were more abundant than females (Fig. 3), especially in the size range between 6 and $48 \mathrm{~mm} \quad(49.43 \%)$ $\left(\chi^{2}=103.789, d f=1, P<0.001\right)$. However, females dominated at sizes greater than $48 \mathrm{~mm}(52.7 \%)$ $\left(\chi^{2}=19.86, \quad d f=1, \quad P<0.001\right) \quad$ (Fig. 3). Sexually undifferentiated individuals were most abundant in the length range 6-48 mm (26.17\%) (Fig. 3).

During this study, two hermaphrodite specimens (43 and $40 \mathrm{~mm}$ in shell length) were detected among a total of 130 individuals examined (Fig. 4A1, A2). Histological examinations of the gonads revealed the presence of both oocytes and spermatozoids inside the same follicle (Fig. 4A1, A2). The lumina of the gonadic tubules were filled with residual spermatozoa (Fig. 4A1a), while the tubule walls consisted of spermatogonia and spermatocytes or oogonia (Fig. 4A1b, A2a, b). 
Table 1 Relationships between biometric variables of Lithophaga lithophaga from the Bay of Bizerte (sexes combined)

\begin{tabular}{|c|c|c|c|c|c|c|}
\hline Biometric variables & Period & $N$ & $\begin{array}{l}y=b x^{\mathrm{a}} \\
\log y=a \log x+\log b\end{array}$ & $t$ & $P$ & Type of growth \\
\hline \multirow[t]{10}{*}{$W$ on $L$} & \multirow[t]{2}{*}{ Annual } & \multirow[t]{2}{*}{975} & $0.294 x^{0.9918}$ & \multirow[t]{2}{*}{3.337} & \multirow[t]{2}{*}{$<0.001$} & \multirow[t]{2}{*}{-} \\
\hline & & & $r=0.96$ & & & \\
\hline & \multirow[t]{2}{*}{ Autumn } & \multirow[t]{2}{*}{292} & $0.2617 x^{1.021}$ & \multirow[t]{2}{*}{4.666} & \multirow[t]{2}{*}{$<0.001$} & \multirow[t]{2}{*}{+} \\
\hline & & & $r=0.97$ & & & \\
\hline & \multirow[t]{2}{*}{ Winter } & \multirow[t]{2}{*}{181} & $0.3863 x^{0.9272}$ & \multirow[t]{2}{*}{11.841} & \multirow[t]{2}{*}{$<0.001$} & \multirow[t]{2}{*}{-} \\
\hline & & & $r=0.95$ & & & \\
\hline & \multirow[t]{2}{*}{ Spring } & \multirow[t]{2}{*}{240} & $0.3133 x^{0.9771}$ & \multirow[t]{2}{*}{4.693} & \multirow[t]{2}{*}{$<0.001$} & \multirow[t]{2}{*}{-} \\
\hline & & & $r=0.96$ & & & \\
\hline & Summer & 262 & $0.2623 x^{1.0173}$ & 918.493 & $<0.001$ & + \\
\hline & & & $r=0.97$ & & & \\
\hline$H$ on $L$ & Annual & 975 & $0.1566 x^{1.1148}$ & 43.157 & $<0.001$ & + \\
\hline & & & $r=0.96$ & & & \\
\hline & Autumn & 292 & $0.1223 x^{1.1765}$ & 36.23 & $<0.001$ & + \\
\hline & & & $r=0.96$ & & & \\
\hline & Winter & 181 & $0.2436 x^{1.0096}$ & 1.581 & n.s. & $=$ \\
\hline & & & $r=0.95$ & & & \\
\hline & Spring & 240 & $0.1852 x^{1.0747}$ & 14.154 & $<0.001$ & + \\
\hline & & & $r=0.96$ & & & \\
\hline & Summer & 262 & $0.1279 x^{1.1611}$ & 32.857 & $<0.001$ & + \\
\hline & & & $r=0.96$ & & & \\
\hline S d. w. on $L$ & Annual & 975 & $\begin{array}{l}\log y=2.613 \log x-4.122 \\
r=0.95\end{array}$ & 14.786 & $<0.001$ & - \\
\hline & Autumn & 292 & $\log y=2.597 \log x-4.116$ & 9.176 & $<0.001$ & - \\
\hline & & & $r=0.96$ & & & \\
\hline & Winter & 181 & $\log y=2.628 \log x-4.142$ & 7.536 & $<0.001$ & - \\
\hline & & & $r=0.97$ & & & \\
\hline & Spring & 240 & $\log y=2.746 \log x-4.332$ & 4.105 & $<0.001$ & - \\
\hline & & & $r=0.94$ & & & \\
\hline & Summer & 262 & $\log y=2.500 \log x-3.924$ & 9.786 & $<0.001$ & - \\
\hline & & & $r=0.95$ & & & \\
\hline ST d. w. on $L$ & Annual & 975 & $\log y=2.611 \log x-4.780$ & 9.498 & $<0.001$ & - \\
\hline & & & $r=0.9$ & & & \\
\hline & Autumn & 292 & $\log y=2.092 \log x-3.981$ & 17.212 & $<0.001$ & - \\
\hline & & & $r=0.92$ & & & \\
\hline & Winter & 181 & $\log y=3.126 \log x-5.689$ & 1.335 & n.s. & $=$ \\
\hline & & & $r=0.93$ & & & \\
\hline & Spring & 240 & $\log y=2.782 \log x-5.001$ & 3.250 & $<0.05$ & - \\
\hline & & & $r=0.94$ & & & \\
\hline & Summer & 262 & $\log y=2.758 \log x-4.969$ & 3.17 & $<0.05$ & - \\
\hline & & & $r=0.91$ & & & \\
\hline T w. w. on $L$ & Annual & 975 & $\log y=2.584 \log x-3.653$ & 14.884 & $<0.001$ & - \\
\hline & & & $r=0.95$ & & & \\
\hline & Autumn & 292 & $\log y=2.763 \log x-4.058$ & 5.532 & $<0.001$ & - \\
\hline & & & $r=0.97$ & & & \\
\hline & Winter & 181 & $\log y=2.576 \log x-3.566$ & 9.414 & $<0.001$ & - \\
\hline & & & $r=0.97$ & & & \\
\hline & Spring & 240 & $\log y=2.527 \log x-3.469$ & 11.084 & $<0.001$ & - \\
\hline & & & $r=0.97$ & & & \\
\hline & Summer & 262 & $\log y=2.524 \log x-3.574$ & 11.116 & $<0.001$ & - \\
\hline & & & $r=0.96$ & & & \\
\hline
\end{tabular}

$L$ shell length, $W$ shell width, $H$ shell height, $S d$. w. shell dry weight, $S T d . w$. soft tissues dry weight, $T w . w$. total dry weight, $N$ number of $N$ number of individuals, n.s. statistically not significant

Positive allometry $(+)$, negative allometry (-), isometry (=) 
Table 2 Relationships between biometric variables of Lithophaga lithophaga from the Bay of Bizerte (sexes separated)

$F$ female, $M$ male, $N$ number of individuals used

Table 3 Results of the ANCOVA

Degree of freedom $=1$

$L$ shell length, $W$ shell width,

$H$ shell height, $S d$. $w$. shell dry weight, $S T d$. w. soft tissues dry weight, $T w . w$. total dry weight

\begin{tabular}{lll}
\hline $\begin{array}{l}\text { Biometric } \\
\text { variables }\end{array}$ & $F$ & $P$ \\
\hline$W$ on $L$ & 12.220 & $<0.001$ \\
$H$ on $L$ & 10.657 & $<0.05$ \\
S d. w. on $L$ & 40.049 & $<0.001$ \\
ST d.w. on $L$ & 25.850 & $<0.001$ \\
T w.w. on $L$ & 81.900 & $<0.001$ \\
\hline
\end{tabular}

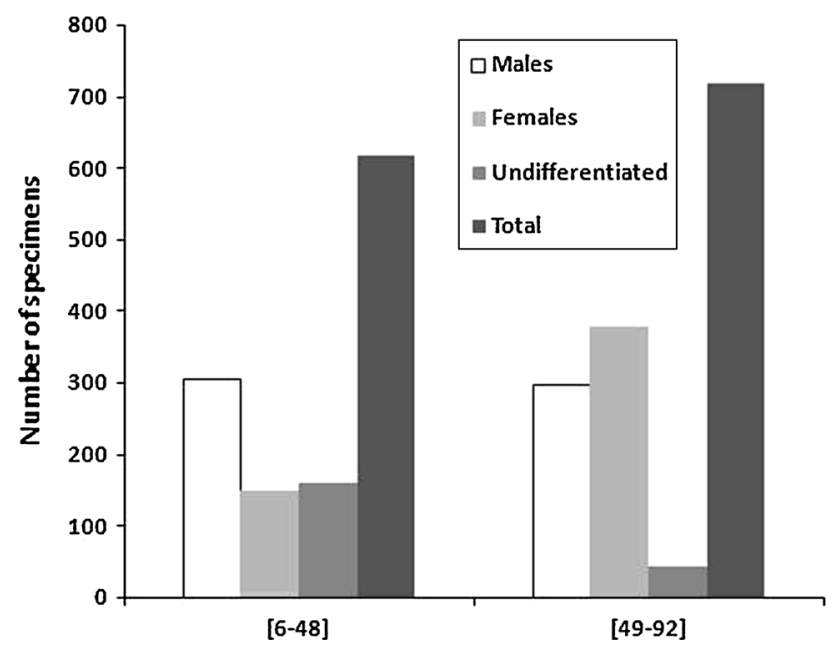

Fig. 3 Frequency of males, females, sexually undifferentiated specimens and total specimens of L. lithophaga in the two size-classes 6-48 and 49-92-mm shell length

\section{Variation of the condition index $(\mathrm{CI})$}

The analysis of the condition index in both sexes showed the presence of a single reproductive cycle per year in $L$. lithophaga. In females, the index increased from $17.28 \pm 4.64$ to
$30.56 \pm 12.79$ from September 2002 to April 2003; in males, an increase from $19.7 \pm 6.57$ to $28.12 \pm 10.5$ recorded from November 2002 to May 2003 (Fig. 5a). During this period, $L$. lithophaga increased in weight which could be partly or totally related to the gonad development. In the following months, the CI values showed only moderate variations (Fig. 5a). A decrease in CI was recorded from August 2003 to September 2003 for females $(27.31 \pm 7.54-20.59 \pm 12.09)$, and from August 2003 to October 2003 for males (27.5 $\pm 10.56-20.5 \pm 7.86)$. Probably, gametes were released during this period. Pairwise comparisons did not show significant differences between the sexes (ANOVA, Tukey, $P>0.05)$.

Variation of the gonadosomatic index (GSI)

Temporal changes in the gonadosomatic index (GSI) were more regular than those recorded for the condition index. The GSI values increased from $9.22 \pm 6.08$ in December 2002 to 13.23 in April 2003 for females, and from $7.9 \pm 4.06$ in November 2002 to $13.77 \pm 7.64$ in June for males (Fig. 5b). Subsequently, a remarkable decrease in value was recorded in August 2003 for females and in September 2003 for males. The index peaked at $13.03 \pm 4.64$ in females and at $10.24 \pm 7.81$ in males. This significant decrease can be explained by a loss of gonad weight that started in August and continued until October. Pairwise comparisons did not show significant differences between the sexes (ANOVA, Tukey, $P>0.05$ ).

Sexual status of the gonad

A microscopic examination of histological sections allowed for the distinction of different gonadal stages 
Fig. 4 Histological sections through the gonad of $L$. lithophaga, showing two cases of hermaphroditism $(A 1, A 2)$. Lumina of the gonadic tubules filled with residual spermatozoa (Ala), tubule walls consisting of spermatogonia and spermatocytes or oogonia ( $A 1 b$, $A 2 a, A 2 b)$. Spg spermatogonia, $\mathrm{Spz}$ spermatozoa, Oog oogonia
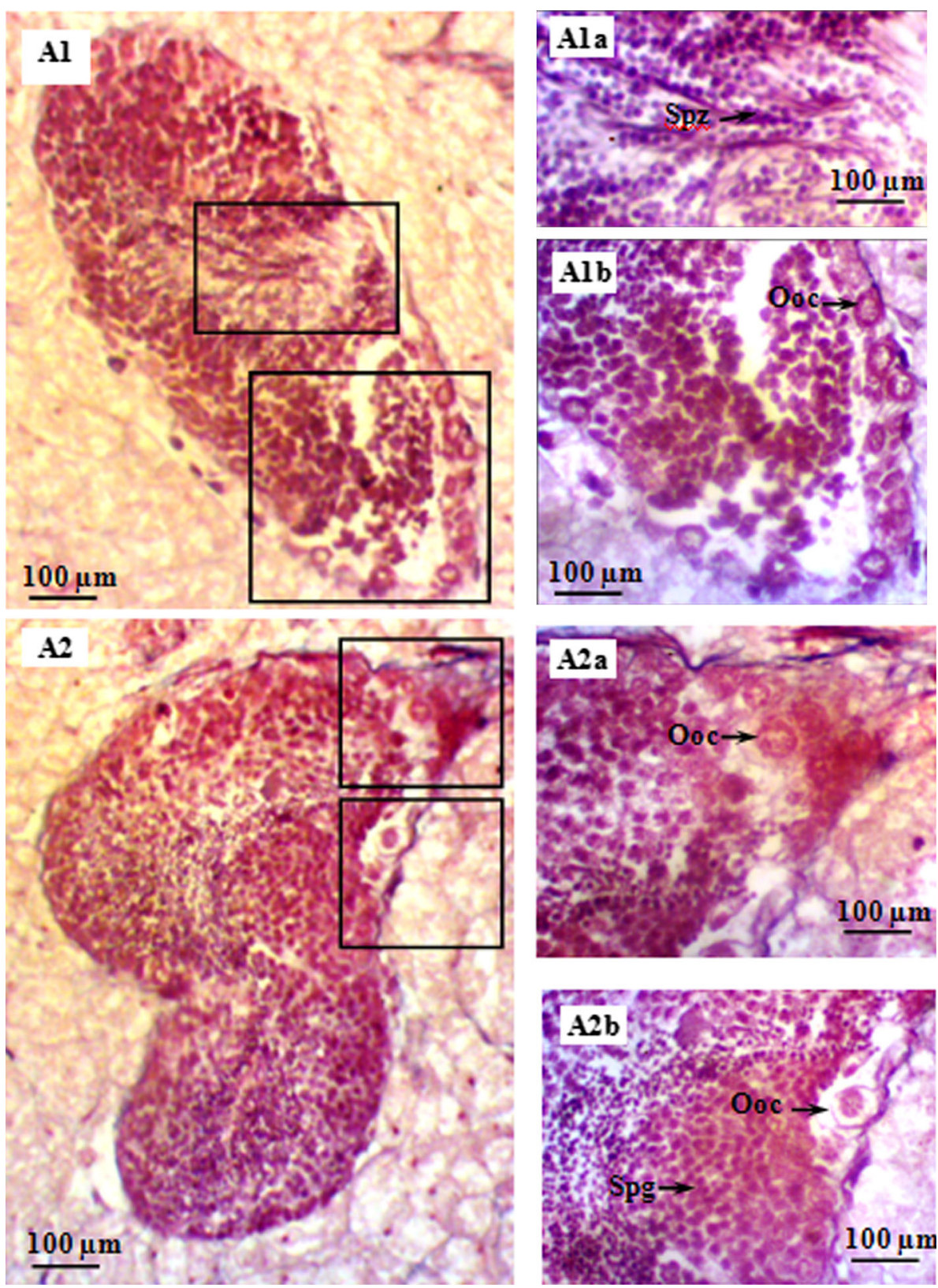

according to Lucas (1965) (Fig. 6a, b). A distinct resting stage (stage A) occurred in both sexes from December to early March (100\% in stage A). Gonads are detectable and sex can be determined only when histological sections reveal the presence of at least a few shrunken follicles and some atretic oocytes (Fig. 7a, e).

In late March and through April and May, gametogenesis started in both sexes (stage B). The highest percentages of early gametogenic stages were recorded in May (74 \% for females and $70 \%$ for males) (Fig. 6a, b).The gonad was then microscopically detectable based on its color. The size of the follicle tended to become larger, and primordial cells were observed in both females and males. In females, oogonia were found on the follicle walls and began to increase in volume (Fig. 7b). In males, the acini largely contained immature gametes (Fig. 7f).

From June to July, vitellogenesis occurred (stage C) and led to an increase in oocyte size. All oocytes were pedunculate (stage $\mathrm{Ca}$ ) and reaching $62 \mu \mathrm{m}$ in diameter at the end of this stage (Fig. 7c). In males, the majority of the acini were full of spermatids and spermatozoids (Fig. $7 \mathrm{~g}$ ). Follicles were larger than in stage $\mathrm{B}$, and the connective tissue was reduced in both sexes. The highest frequency of this stage was recorded in June $(91 \%$ for females and $75 \%$ for males) (Fig. 6a, b). 

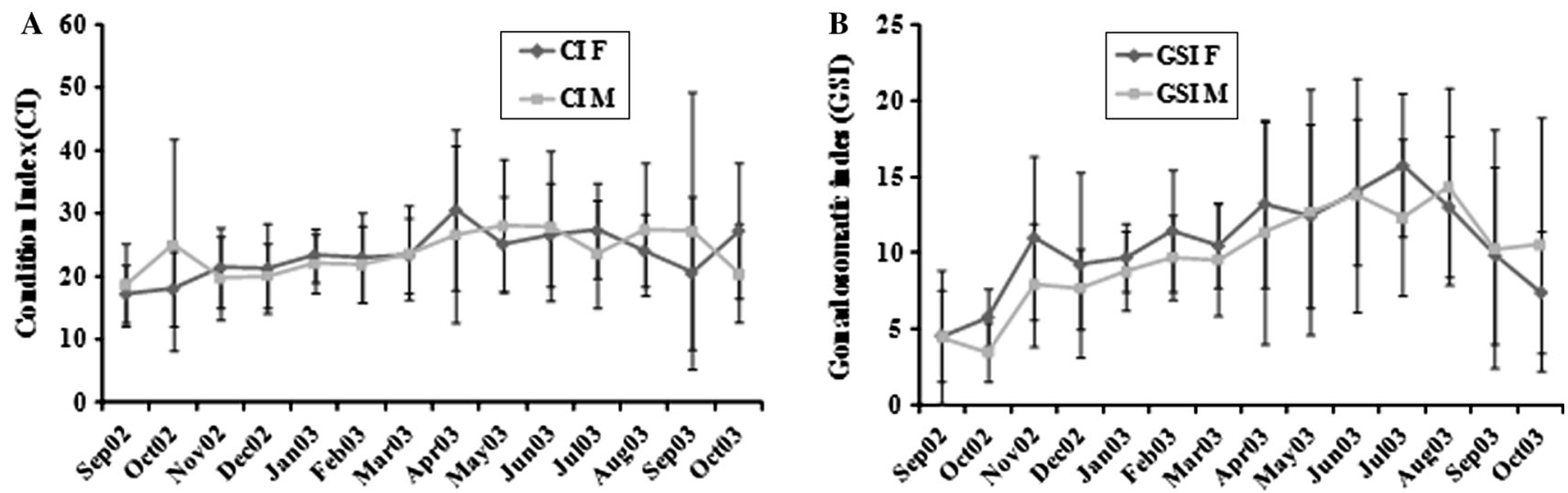

Fig. 5 Monthly variations in the conditions index CI (a) and the gonadosomatic index GSI (b) of male and female L. lithophaga during the study period (mean $\pm \mathrm{SD}, n=50-100$ )
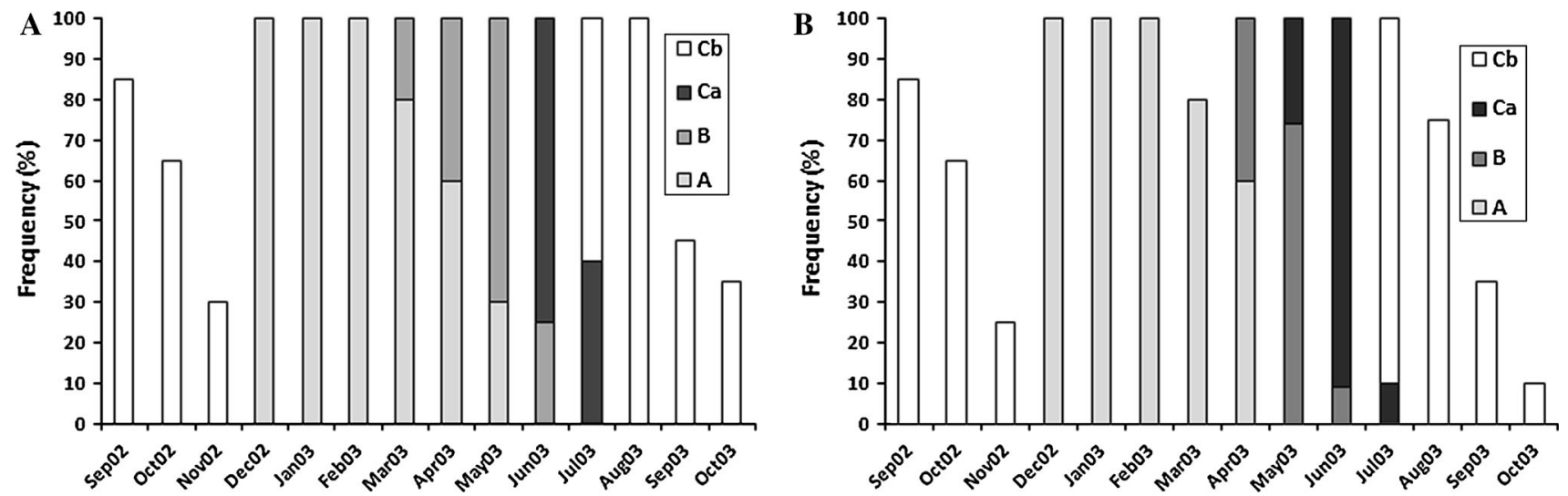

Fig. 6 Monthly frequencies of the different gonadal maturation stages $(\mathbf{a}, \mathbf{b}, \mathrm{Ca}, \mathrm{Cb})$ in females (a) and males (b) of L. lithophaga

From late July to November (stage $\mathrm{Cb}$ ), the majority of gametes were mature. The female gonad was completely filled with free oocytes $(85-123 \mu \mathrm{m}$ in diameter) with regular shape (Fig. 7d). In males, the gonadal acini mainly contained highly mobile spermatozoids (Fig. 7h). The frequency of mature individuals was highest in July for females $(90 \%)$ and in August for males (100\%) (Fig. 6a, b). Throughout this period, spawning occurred and resulted in a nearly total emission of gametes in both sexes. Sexual activity was completely reduced in late November, when unreleased sex cells became gradually resorbed.

\section{Discussion}

The present study of growth parameters of L. lithophaga collected from Bizerte Bay has demonstrated that shell dry weight (S d.w.), soft tissues dry weight (ST d.w.) and total wet weight (T w.w.) in both sexes increased at a slower rate than shell length $(L)$ (=negative allometry). In contrast, a positive allometry was found for shell height $(H)$ in both sexes. With respect to shell width $(W)$, a negative allometric relationship was recorded for females, while the relationship for males was isometric. According to literature data, L. lithophaga has the lowest growth rate of all studied species of the family Mytilidae (Galinou-Mitsoudi and Sinis 1995; Katsanevakis et al. 2008). This slow growth is probably related to the longevity of this species, which can live for more than 54 years (Galinou-Mitsoudi and Sinis 1995). These authors also showed that individuals of $15-52 \mathrm{~mm}$ in length have an age of 6-25 or even up to 36 years.

The statistical analyses showed significant differences between females and males with respect to the relationships between shell length $(L)$ and the parameters W, H, S d.w., ST d.w. and T w.w. In males, these parameters increased faster (relative to $L$ ) than in females. This does not mean, however, that males reach bigger sizes than females, as the latter are dominant among the biggest individuals. These observations correspond to those reported by Valli et al. (1986) and Galinou-Mitsoudi and Sinis (1995), who showed that males of the date mussel 
Fig. 7 Histological sections through the gonads of male and female $L$. lithophaga at various developmental stages; a,

e resting stage; $\mathbf{b}, \mathbf{f}$ initiation of gametogenesis; c,

g vitellogenesis; $\mathbf{d}, \mathbf{h}$ maturity. Scale bar $100 \mu \mathrm{m}$
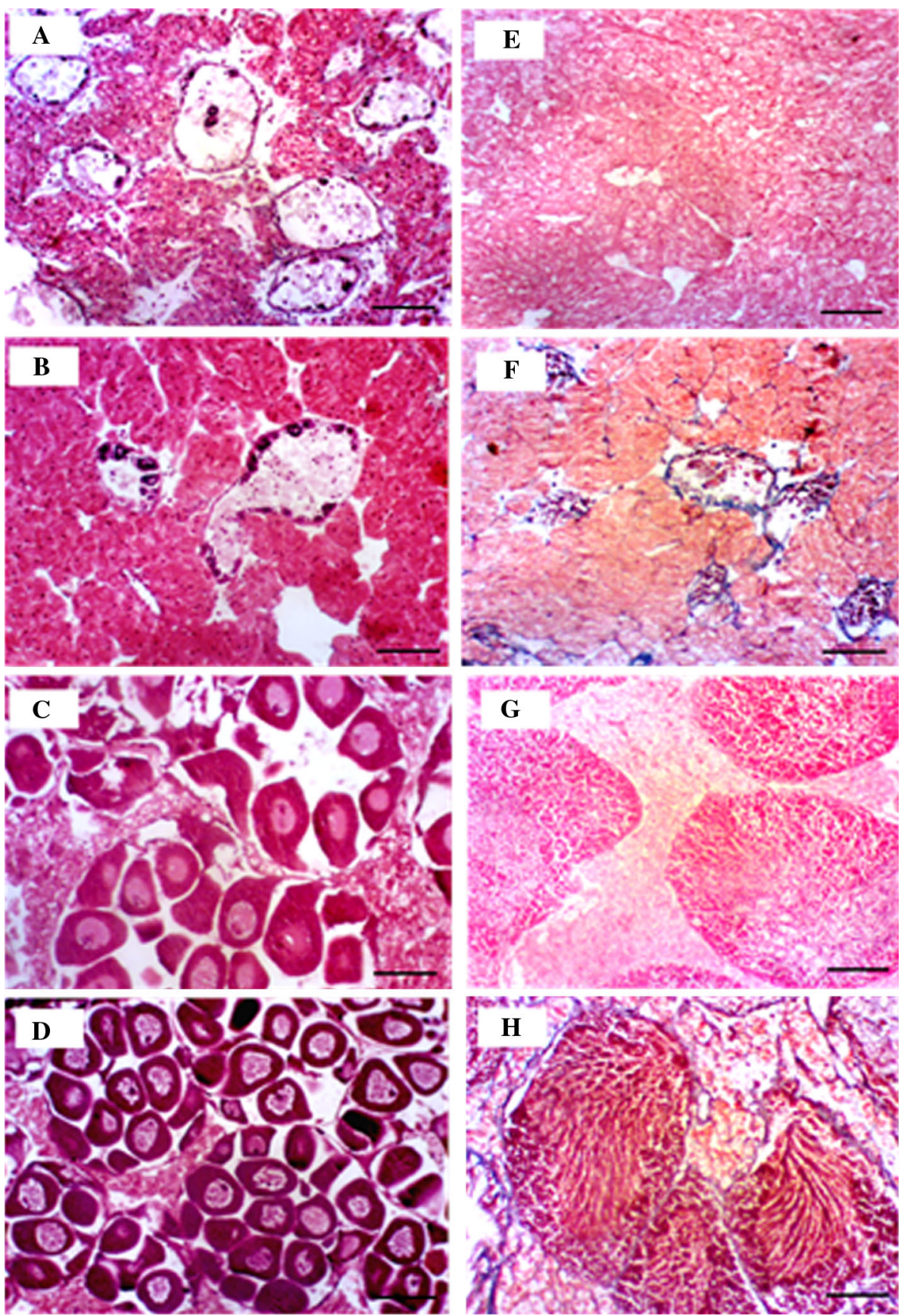

collected from the northern Adriatic and the North Evoikos Gulf, have lower values of length, width and height than females. Valli et al. (1986) considered this size difference as an indicator of sexual dimorphism, while GalinouMitsoudi and Sinis (1995) attributed this difference to the fact that females live longer than males.

The relationships between biometric variables and shell length changed seasonally. Negative allometries were recorded for all variables except for $W, H$ and ST d.w. which showed positive allometries in autumn and summer for shell width and in autumn, spring and summer for shell height. However, isometric relationships were registered for both $H$ and St d.w. on $L$. These variations are likely related to environmental and physiological conditions such as the gonad status (Wilbur and Owen 1964). Indeed, temperature, salinity, nutrient availability and hydrodynamics are factors that affect the growth of bivalves (Seed 1976). Various abiotic and biotic factors can affect the growth rate of date mussels, among them particularly the composition of the substratum, hydrodynamic conditions, habitat physical features, food concentration and intraspecies competition for food and space (Kleemann 1973; Valli et al. 1986; Galinou-Mitsoudi and Sinis 1995, 1997; Devescovi 2009). According to Ben Garali et al. (2009), 
Table 4 Comparisons between some parameters of Lithophaga lithophaga from the Mediterranean and the Adriatic Seas

\begin{tabular}{|c|c|c|c|}
\hline & & $\begin{array}{l}\text { Bay of Bizerte } \\
\text { (Northern } \\
\text { Tunisia) }\end{array}$ & $\begin{array}{l}\text { Area of Split } \\
\text { (middle } \\
\text { Adriatic) }\end{array}$ \\
\hline \multicolumn{2}{|c|}{$\begin{array}{l}\text { Total wet weight (with } \\
\text { intervalvular water) }\end{array}$} & $\begin{array}{l}\text { Negative } \\
\text { allometry }\end{array}$ & $\begin{array}{l}\text { Isometric } \\
\text { growth }\end{array}$ \\
\hline \multicolumn{2}{|l|}{ Sex ratio } & $1.13: 1$ & $1.3: 1$ \\
\hline \multirow[t]{5}{*}{$\begin{array}{l}\text { Reproductive } \\
\text { period }\end{array}$} & Resting stage & $\begin{array}{l}\text { From } \\
\text { December to } \\
\text { March } \\
(T \text { between } \\
11.5 \text { and } \\
\left.16.8^{\circ} \mathrm{C}\right)\end{array}$ & $\begin{array}{l}\text { During the cold } \\
\text { season, from } \\
\text { December to } \\
\text { early April } \\
\left(T<14{ }^{\circ} \mathrm{C}\right)\end{array}$ \\
\hline & $\begin{array}{l}\text { Proliferation of } \\
\text { the gonad and } \\
\text { differentiation } \\
\text { of the gametes }\end{array}$ & $\begin{array}{l}\text { In early April } \\
\text { and May } \\
(T \text { between } \\
18.2 \text { and } \\
\left.20^{\circ} \mathrm{C}\right)\end{array}$ & $\begin{array}{l}\text { In April, May } \\
\text { and June } \\
\text { ( } T \text { between } \\
14 \text { and } \\
\left.20^{\circ} \mathrm{C}\right)\end{array}$ \\
\hline & $\begin{array}{l}\text { Advanced } \\
\text { gametogenesis }\end{array}$ & $\begin{array}{l}\text { From June to } \\
\text { July } \\
\left(T>26^{\circ} \mathrm{C}\right)\end{array}$ & $\begin{array}{l}\text { From June to } \\
\text { beginning of } \\
\text { July } \\
\left(T>20{ }^{\circ} \mathrm{C}\right)\end{array}$ \\
\hline & $\begin{array}{l}\text { Maturation and } \\
\text { spawning }\end{array}$ & $\begin{array}{l}\text { Late July, end } \\
\text { of August } \\
\text { and early } \\
\text { September } \\
\text { ( } T \text { between } \\
25.1 \text { and } \\
35^{\circ} \mathrm{C} \text { ) }\end{array}$ & $\begin{array}{l}\text { Early July, } \\
\text { August and } \\
\text { late } \\
\text { September } \\
\text { ( } T \text { between } \\
22 \text { and } \\
27^{\circ} \mathrm{C} \text { ) }\end{array}$ \\
\hline & Spent stage & $\begin{array}{l}\text { November } \\
\qquad\left(T<20^{\circ} \mathrm{C}\right)\end{array}$ & $\begin{array}{l}\text { November } \\
\qquad\left(T<20^{\circ} \mathrm{C}\right)\end{array}$ \\
\hline
\end{tabular}

freshwater discharged from the lagoon of Bizerte to the bay of Bizerte during the winter carry suspended matter and nutrients that allow the date mussel to increase in somatic and gonadic weight. This weight gains in the soft tissues, which decrease in spring, summer and autumn, are probably due to an increased physiological activity of the date mussel certainly related to the temperature rise at the same time.

According to Trevallion and Ansell (1967), the weight of Tellina tenuis (Da Costa 1778) changes rapidly with environmental conditions such as the presence/absence of sufficient amounts of nutrients. Other studies have shown that the quality and quantity of the available seston are major factors influencing the growth rate of mytilids (Hawkins et al. 1997). However, the date mussel is an endolithic species that needs to broaden its tunnel during its growth. This requires a large amount of energy (Šimunović et al. 1990), which is thus not available for somatic growth and gamete production. According to Kleemann (1973), the digging activity of L. lithophaga in the Adriatic Sea is particularly high in autumn $(1-3 \mathrm{~mm})$, while it decreases in winter and mainly in spring. The weight loss during spring, summer and autumn may thus be due to both gamete release and an increased allocation of energy to the perforation of the habitat.

The overall sex ratio was found to be unbalanced in the population of L. lithophaga collected in the Bay of Bizerte. This observation agrees with those reported for $L$. lithophaga populations collected from the area of Split (middle Adriatic) (Table 4). Valli et al. (1986) also showed a predominance of males $(64.33 \%)$ in the population of the gulf of Trieste. Similarly, Šimunović et al. (1990) revealed the presence of $56.3 \%$ of males collected from the central Adriatic Sea (Table 4). In the North Evoikos Gulf, a male predominance $(72.86 \%)$ was recorded among individuals up to 70-mm shell length, whereas the sex ratio was balanced among individuals which were larger than $70 \mathrm{~mm}$ (Galinou-Mitsoudi and Sinis 1994). In the present study, the sex ratio among individuals up to $48 \mathrm{~mm}$ was 2.03 (males):1(females), but many individuals of this size class were still sexually undifferentiated. Among individuals larger than $48 \mathrm{~mm}$, however, the sex ratio became more balanced (0.78:1). Therefore, the male-biased sex ratio of L. lithophaga might simply result from the fact that females mature at larger shell sizes than males.

In this study, only two cases of hermaphroditism were detected in L. lithophaga which could be an accidental phenomenon. Other cases of occasional hermaphroditism have been recorded in some bivalves such as Mytilus edulis and Mytilus galloprovincialis (Lubet 1959), Ruditapes decussatus (Delgado and Camacho 2002) and Perumytilus purpuratus (Montenegro et al. 2010). Some authors associate occasional hermaphroditism with endocrine disruptors such as organotin, urban and industrial pollution (Montenegro et al. 2010). In our case, additional studies will be necessary to link the hermaphroditism occurrence in L. lithophaga to pollution and endocrine disruption.

The temporal changes in the CI and GSI indexes were largely similar and revealed a high degree of synchrony in the gonadal development of both sexes. However, the CI values fluctuated markedly which made it difficult to define the spawning period. In contrast, the GSI values were more consistent, allowing for a better characterization of the reproductive cycle. There was a sexual resting period in winter coinciding with the lowest water temperatures $\left(11.5^{\circ} \mathrm{C}\right)$. This result is confirmed by the examination of histological gonad sections. In spring, the water temperature increased to $18.2{ }^{\circ} \mathrm{C}$ in April, which stimulated the initiation of gametogenesis and the proliferation of gametes. Follicles became larger and the gamete stock increased. From June to July, the advanced stages of gametogenesis occurred. In females, oocytes remained attached to the follicular wall via the peduncule. In males, the majority of acini were full of spermatids and spermatozoids. The main spawning occurred at the end of August and in early September when water 
temperature and salinity decrease from 35 to $25.1^{\circ} \mathrm{C}$ and from 37.7 to 37.0 , respectively. The gonad sections showed ripe gametes. Oocytes were regular in shape, and spermatozoids were flagellated. Most gametes were released at this stage. These results are similar to those recorded by Šimunović et al. (1990) in the Adriatic date mussel (Table 4). In fact, these authors registered several spawning events from late June to mid-October. The temperature during this period was higher than $22{ }^{\circ} \mathrm{C}$. According to the same authors, the gametogenetic activity was reduced in autumn, associated with a decrease in water temperature. Galinou-Mitsoudi and Sinis (1994) reported that the period of full maturity extended mainly from July to November, and the release of gametes began immediately after a decline in the highest water temperature $\left(\leq 27^{\circ} \mathrm{C}\right)$ and an increase in salinity (>31\%o).

This confirms that the length and the timing of the reproductive cycle in bivalves depend on environmental factors (seawater temperature, salinity, abundance of food), the action of which may be meditated by neurosecretions (Šimunović et al. 1990; Lemaire et al. 2006). In the same context, Lubet $(1984,2001)$ showed that temperature is a decisive ecological factor in the evolution of the reproductive cycle of bivalves. The author revealed that this variable can disrupt and even stop the gametogenesis in bivalves. According to Lubet (1984), spawning in Crassostrea gigas (Thunberg 1793) cannot occur when the temperature is below $21{ }^{\circ} \mathrm{C}$. Moreover, at a lower temperature, oocytes disintegrate and cannot be issued from the gonad. Concerning salinity, the same author showed in Mytilus edulis (Linnaeus 1758) that it is difficult to separate the effects of salinity and temperature because both accelerate or delay the onset of gamete release.

Trophic factors also affect the gametogenesis in bivalves. In fact, insufficient amounts of phytoplankton could delay gametogenesis in Mya arenaria and M. edulis (Gauthier-Clerc et al. 2002; Cartier et al. 2004; Lemaire et al. 2006).

The present paper contributes to the knowledge on the biology and particularly the reproductive cycle of the endangered species ('red list') L. lithophaga. The information may be useful for proposing management measures to protect local wild stocks.

Acknowledgments The first author would like to thank the Editorin-chief and two anonymous reviewers for their valuable comments and suggestions that greatly improved the manuscript.

\section{References}

Ballèvre M, Lardeux H (2005) Signification paléoécologique et paléogéographique des bivalves du Carbonifère inférieur du bassin d'Ancenis (Massif armoricain). CR Palevol 4:109-121
Ben Garali A, Ouakad M, Gueddari M (2009) Transfert d'eau et de matières entre la Lagune et la Baie de Bizerte via le canal de Bizerte (Tunisie Septentrionale). Revue de la Faculté des Sciences de Bizerte 7:23-28

Cartier S, Pellerin J, Fournier M, Tamigneaux E, Girault L, Lemaire N (2004) Use of an index based on the blue mussel (Mytilus edulis and Mytilus trossulus) digestive gland weight to assess the nutritional quality of mussel farm sites. Aquaculture 241:633-654

Delgado M, Camacho AP (2002) Hermaphroditism in Ruditapes decussatus (L.) (Bivalvia) from the Galician coast (Spain). Sci Mar 66:183-185

Deudero S, Box A, March D, Valencia JM, Grau AM, Tintore J, Calvo M, Caixach J (2007) Organic compounds temporal trends at some invertebrate species from the Balearics, Western Mediterranean. Chemosphere 68:1650-1659

Devescovi M (2009) Biometric differences between date mussels Lithophaga lithophaga colonizing artificial and natural structures. Acta Adriat 50:129-138

Devescovi M, Iveša L (2008) Colonization patterns of the date mussel Lithophaga lithophaga (L., 1758) on limestone breakwater boulders of a marina. Periodicum Biologorum 110:339-345

Devescovi M, Ozretić B, Iveša L (2005) Impact of date mussel harvesting on the rocky bottom structural complexity along the Istrian coast (Northern Adriatic, Croatia). J Exp Mar Biol Ecol 325:134-145

Dujmov J, Sučević P (1990) The contamination of date shell (Lithophaga lithophaga) from the eastern coast of the Adriatic Sea by polycyclic aromatic hydrocarbons. Acta Adriat 31:153-161

El bour M, Jaafar Kefi F, Hamrouni M, Mahmoud N, Dellali M, Trigui El Menif N, Aloui Bejaoui N (2008) Etude de dépistage de la maladie de l'anneau brun chez des espèces de bivalves des côtes tunisiennes. Bull Soc Zool Fr 133:107-115

Fanelli G, Piraino S, Belmonte G, Geraci S, Boero F (1994) Human predation along Apulian rocky coasts (SE Italy): desertification caused by Lithophaga lithophaga (Mollusca) fisheries. Mar Ecol Prog Ser 110:1-8

FAO (2004) Rapport du groupe consultatif spécial d'experts chargé de l'évaluation des propositions d'amendement des annexes I et II de la Cites concernant les espèces aquatiques faisant l'objet de commerce. FAO, Rome, Rapport sur les pêches no 748

Fischer W, Bauchot M, Schneider M (1987) Fiches FAO d'identification des espèces pour les besoins de la pêche (Révision1). Méditerranée et Mer Noire, Zone de Pêche 37, Vol 1, Végétaux et invertébrés. FAO, Rome

Fraschetti S, Bianchi TA, Fanelli G, Morri C, Boero F (2001) Spatial variability and human disturbance in shallow subtidal hard substrate assemblages: a regional approach. Mar Ecol Prog Ser 212:1-12

Galinou-Mitsoudi S, Sinis AI (1994) Reproductive cycle and fecundity of the date mussel, Lithophaga lithophaga (Bivalvia: Mytilidae). J Mollus Stud 60:371-385

Galinou-Mitsoudi S, Sinis AI (1995) Age and growth of Lithophaga lithophaga (Linnaeus, 1758) (Bivalvia: Mytilidae), based on annual growth lines in the shell. J Mollus Stud 61:435-453

Galinou-Mitsoudi S, Sinis AI (1997) Population dynamics of the date mussel, Lithophaga lithophaga, (L., 1758) (Bivalvia: Mytilidae) in the Evoikos Gulf (GREECE). Helgoländer Meeresunters $51: 137-154$

Gargominy O, Bouchet P, Moreno D (1999) Lithophaga lithophaga (Linné, 1758) Muséum national d'Histoire Naturelle

Gauthier-Clerc S, Pellerin J, Blaise C, Gagné F (2002) Delayed gametogenesis of Mya arenaria in the Saguenay fjord (Canada): a consequence of endocrine disruptors? Comp Biochem Phys C $131: 457-467$ 
Gilli É, Audra P (2004) Les lithophages pliocènes de la fontaine de Vaucluse (Vaucluse, France): un argument pour une phase messinienne dans la genèse du plus grand karst noyé de France. Compte Rendus Géosciences 336:1481-1489

Gonzalez JT, Halcon RMA, Barrajon A, Calvo M, Frias A, Morreno D, Saavedra L (2000) Estudio sobre la biologia, conservación y problemática del dátil de mar (Lithophaga lithophaga) en Espana. Madrid, Ministerio de Medio Ambiente, Dirección General de Conservación de la Naturaleza

Guidetti P, Boero F (2004) Desertification of Mediterranean rocky reefs caused by date-mussel, Lithophaga lithophaga (Mollusca: Bivalvia), fishery: effects on adult and juvenile abundance of a temperate fish. Mar Pollut Bull 48:978-982

Guidetti P, Fanelli G, Fraschetti S, Terlizzi A, Boero F (2002) Coastal fish indicate human-induced changes in the Mediterranean littoral. Mar Environ Res 53:77-94

Guidetti P, Fraschetti S, Terlizzi A, Boero F (2003) Distribution of sea urchins and barrens in shallow mediterranean rocky reefs impacted by the illegal fishery of the rock-boring molluscs Lithophaga lithophaga. Mar Biol 143:1135-1142

Hawkins AJS, Smith RFM, Bougrier S, Bayne BL, Héral M (1997) Manipulation of dietary conditions for maximal growth in mussels Mytilus edulis from the Marennes Oléron-Bay, France. Aquat Living Resour 10:13-22

Jaafar Kefi F, Trigui El Menif N, Le Pennec M, Boumaiza M (2004) Perturbations coquillières chez le mollusque bivalve Lithophaga lithophaga prélevée dans la baie de Bizerte (Tunisie). Bull Soc Zool Fr 4:419-426

Jaafar Kefi F, Trigui El Menif N, Boumaiza M (2007) Étude comparative de la croissance relative saisonnière chez le bivalve Lithophaga lithophaga (linné, 1758) prélevé dans la lagune et la baie de Bizerte (Tunisie). Rapport des Communications Internationnales de la Mer Méditérranée 38:p516

Jaafar Kefi F, Lahbib Y, Gargouri Ben Abdallah L, Trigui El Menif N (2012a) Shell disturbances and butyltins burden in commercial bivalves collected from the Bizerta lagoon (northern Tunisia). Environ Monit Assess 184:6869-6876

Jaafar Kefi F, Gargouri Ben Abdallah L, Trigui El Menif N, Mraouna R, El Bour M (2012b) Health status of the date mussel Lithophaga lithophaga (Linné, 1758) from the North of Tunisia. Cah Biol Mar 53:177-184

Katsanevakis S, Lefkaditou E, Galinou-Mitsoudi S, Koutsoubas D, Zenetos A (2008) Molluscan species of minor commercial interest in Hellenic seas: distribution, exploitation and conservation status. Mediterr Mar Sci 9:77-118

Kleemann K (1973) Lithophaga lithophaga (L.) (Bivalvia) in different limestone. Malacologia 14:345-347

Lemaire N, Pellerin J, Fournier M, Girault L, Tamigneaux E, Cartier S, Pelletier E (2006) Seasonal variations of physiological parameters in the blue mussel mytilus spp. from farm sites of eastern Quebec. Aquaculture 261:729-751

Lubet P (1959) Recherches sur le cycle sexuel et l'émission des gamètes chez les mytildés et les pectinidés (Mollusques, Bivalves). Rev Trav Inst Pêches Marit 23:395-548

Lubet P (1984) Biologie de la reproduction de mollusques bivalves d'importance commerciale en méditerranée. Haliotis 14:49-68

Lubet P (2001) Agents de stress dans les élevages en conchyliculture. Bull Soc Zool Fr 126:7-21
Lucas A (1965) Recherche sur la sexualité des mollusques bivalves. Université de Rennes, Thèse de Doctorat en Sciences Naturelles

Martoja M, Martoja R (1967) Initiation aux techniques de l'histologie animale. Edition Masson \& Cie, Paris

Mayrat A (1959) Nouvelle méthode pour l'étude comparée d'une croissance relative dans deux échantillons. Application à la carapace de Penaeus kerathurus. Bulletin de l'Institut français d'Afrique noire 21:21-59

Mojetta A, Ghisotti A (1996) Flore et faune de la méditerranée. Collection Guide vert

Montenegro VD, Olivares PA, González MT (2010) Hermaphroditism in marine mussel Perumytilus purpuratus (Lamarck, 1819), (Mollusca: Mytilidae). Int J Morphol 28:569-573

Morton B, Scott PJB (1980) Morphological and functional specialization of the shell, musculature and pallial glands in the Lithophaginae (Mollusca: Bivalvia). J Zool 192:179-203

Owada M (2009) Organic sheets in the shells of endolithic mytilids (Bivalvia: Mytilidae). Paleontol Res 13:159-166

Parravicini V, Morri C, Ciribilli G, Montefalcone M, Albertelli G, Bianchi CN (2009) Size matters more than method: visual quadrats vs photography in measuring human impact on Mediterranean rocky reef communities. Estuar Coast Shelf Sci 81:359-367

Poutiers JM (1987) BIVALVES. Fiches FAO d'identification des espèces pour les besoins de la pêche-Méditerranée et mer noire. Zone de pêche 37(Revision 1):440-446

Seed R (1976) Ecology. In: Bayne BL (ed) Marine mussels. Cambridge University Press, Cambridge, pp 13-65

Shafee MS (1999) Pêche des Bivalves sur la côte méditerranéenne Marocaine. Catalogue d'espèces exploitées et d'engins utilisés. Pour la FAO-COPEMED, ALICANE, Espagne

Šimunović A, Grubelić I, Tudor M, Hrs- Brenko M (1990) Sexual cycle and biometry of the date shell Lithophaga lithophaga Linnaeus (Mytilidae). Acta Adriat 31:139-151

Trevallion A, Ansell AD (1967) Studies on Tellina tenuis Da Costa. Preliminary experiments in enriched sea water. J Exp Mar Biol Ecol 1:257-270

Trigui El Menif N, Jaafar Kefi F, Ramdani M, Flower R, Boumaiza M (2007) Habitat and associated fauna of Lithophaga lithophaga (Linné 1758) in the bay of Bizerta (Tunisia). J Shellfish Res 26:569-574

Valli G, Nodari P, Sponza R (1986) Allevamento sperimentale di Lithophaga lithophaga (L) (Bivalvia, Mytilacea) e studio del ciclo riproduttivo nel Golfo di Trieste (Experimental rearing of Lithophaga lithophaga (L) (Bivalvia Mytilacea) and study of the reproductive cycle in the Gulf of Trieste). Nova Thalass 8:1-13

Walne PR, Mann R (1975) Growth and biochemical composition in Ostrea edulis and Crassostrea gigas. In: Barnes H (ed) Proceeding ninth european marine biology symposium. Aberdeen University Press, Aberdeen, pp 587-607

Wilbur KM, Owen G (1964) Growth. In: Wilbur KM, Yonge CM (eds) Physiology of Mollusca, vol I. Academic Press, New York, pp 211-237

Zar JH (1984) Biostatistical analysis, 2nd edn. Prentice-Hall, Englewood Cliffs 